\title{
The Customer Engagement Effect on Customer Satisfaction and Brand Trust and Its Impact on Brand Loyalty
}

\author{
Meylani Tuti* and Viki Sulistia
}

\begin{abstract}
:
Research aims: The research purpose is to determine the influence of customer engagement on brand loyalty through customer satisfaction and brand trust. Design/Methodology/Approach: The population in this research was customers who made purchases from December 2019 until February 2020. The sampling technique employed purposive sampling to decide on 200 respondents. The data had been examined for reliability and validity. The data analysis method used quantitative and descriptive. Structural Equation Modeling (SEM) was utilized in the quantitative analysis.

Research findings: The research results uncovered that customer engagement significantly influenced customer satisfaction. Customer engagement gave a significant influence on brand trust. Customer engagement gave a significant influence on brand loyalty. Customer satisfaction gave a significant influence on brand trust. The brand trust gave a significant influence on brand loyalty. Customer engagement gave an indirect influence on brand trust through customer satisfaction. Also, customer engagement indirectly influenced brand loyalty through brand trust and customer satisfaction.

Theoretical contribution/Originality: The study gives contribution to the growth of brand literature.

Practitioner/Policy implication: The study has implications for researchers and sellers on how to improve the brand.

Research limitation/Implication: The limitation of this study is that it only used one clothing entrepreneurship business brand that utilized Instagram as a promotional medium for further research. Developing the research object further by using more similar brands is recommended.

Keywords: Customer Engagement; Customer Satisfaction; Brand Trust; Brand Loyalty
\end{abstract}

\section{CITATION:}

Tuti, M., \& Sulistia, V. (2022). The Customer Engagement Effect on Customer Satisfaction and Brand Trust and Its Impact on Brand Loyalty. Jurnal Manajemen Bisnis, 13(1), 1-15.

\section{ARTICLE HISTORY}

Received:

10 Aug 2021

Revised:

05 Sep 2021

24 Dec 2021

Accepted:

10 Jan 2022

\section{Introduction}

The development of online shopping in Indonesia is fast. Many people choose to do online shopping, especially in the pandemic era, not only because they can see the kinds of products and services given by the shoppers but also because it is the easiest; it is the most reason for the customer. In this case, idea, creativity, and innovation have become the main mover for society to build their new businesses. 
Tuti \& Sulistia

The Customer Engagement Effect on Customer Satisfaction ...

Along with technology development and the spread of the internet, this situation has given the easiest way for the sellers to promote their product to their customers. There are two sides to online shopping: first, from the customer's perspective, and second, from the seller's perspective. As the sellers, it is essential to attract customers to know their product, be aware of their brand and how to handle them, and make them loyal customers. As customers, they feel satisfied with the products and services, making them aware of and trusting the brand.

Moreover, marketing 4.0 is an approach that collaborates offline and online interactions between customers and companies. In the digital economy, digital interactions alone are not enough. In an increasingly transparent world, authenticity becomes the most valuable asset. Finally, marketing 4.0 leverages artificial intelligence and machine-to-machine connectivity to increase marketing productivity while leveraging human-to-human connectivity to strengthen customer engagement.

In this case, social media is one type of media with one distinguishing characteristic: it combines the social interaction of technology to create shared value and content. It indicates that people use it for conversations and social interactions (Kaplan \& Haenlein, 2010; Strauss \& Frost, 2014) Social media is the common tool sellers utilize to introduce their products and manage their customers by always giving them information as a reminder of their brand.

Furthermore, involving the customer in the business can be a bridge that allows it to continue to generate the expected profits. Customer engagement is the intensity of individual participation and its relationship with company activities or offers made by customers or companies (Vivek et al., 2012). Meanwhile, Hollenbeck asserted that customer engagement is the level of individual motivation related to the brand and the dependence on the consumer's context, which is characterized by the level of emotional, cognitive, and certain indirect brand interaction behavior (Hollebeek, 2011). The process of engaging customers or consumers in marketing activities can occur offline and online. Offline, customers and producers interact directly, such as when making a transaction. Meanwhile, online activity occurs when producers take advantage of social media platforms to reach more customers and broadly introduce the products or services they offer. It will bring them to customer satisfaction, in which it is defined that customer satisfaction is cumulative satisfaction, also known as the final assessment of customers according to their experience with the brand of product (Han et al., 2018).

Andersen et al. stated that increasing customer satisfaction is expected to increase customer retention to provide greater profitability. The potential effect of customer satisfaction can be influenced by brand image by comparing differences in user and nonuser perceptions of a brand (Anderson \& Mittal, 2000). This customer satisfaction occurs after consumers make purchases of the products. They get what they expect. Customer satisfaction can be formed through consumer affective responses, such as enjoyment, joy, and pleasure when having the experience of using the services of a brand or company. In this regard, trust constitutes an important driver in a connection since it can reduce the risk of less responsiveness and make customers' perceptions more effective than others. 
Tuti \& Sulistia

The Customer Engagement Effect on Customer Satisfaction ...

Brand trust is defined as the intention of the average customer relying on the brand's ability to implement its stated functions (Chaudhuri \& Holbrook, 2001). Meanwhile, Zehir affirmed that brand trust includes a process that is thought out well and considered carefully (Zehir et al., 2011).

On the other side, brand loyalty is seen as a positive response after a customer makes a purchase and feels happy and satisfied with the quality of benefits of a product and the benefits provided by the brand (Shanahan et al., 2019). This brand loyalty occurs after consumers get satisfied with the products and services given by a brand, and they trust the brand so that it is hoped that customers will make repeat purchases, and customers will think again and will not even switch to another brand. Previous research has found that customer engagement influenced customer satisfaction and brand trust positively but had no effect on brand loyalty (Rahmawati \& Aji, 2015). Hwang et al. (2021) unveiled that customer satisfaction and trust affected customer behavior in terms of loyalty; customer engagement was found to be positively associated with customer trustworthiness (Kosiba et al., 2018). Meanwhile, others uncovered that brand attitudes affected brand loyalty negatively (Cho et al., 2015). Therefore, the objective of this study is to investigate the influence of customer engagement through customer satisfaction and brand trust on brand loyalty.

\section{Literature Review and Hypotheses Development}

\section{Customer Engagement}

Customer engagement is the intensity of participation of individuals and creativity with the company offers or activities carried out by customers or companies (Vivek, 2009). Meanwhile, another definition states that engagement of customer is the level of motivation of an individual, which is related to the brand, and the dependence on the consumer's context, which is characterized by the level of an emotional, cognitive, and specific indirect brand interaction behavior (Hollebeek, 2011). The five dimensions to measure customer engagement are enthusiasm, interaction, attention, absorption, and identification (So et al., 2014).

The intense relationship between the customer and the company can affect customer satisfaction, based on the customer's level of relationship and emotional interaction (Sashi, 2012). Satisfaction is in the form of affective responses such as joy and pleasure when customers use company services (Gummerus et al., 2012). If in their interactions, the service or response of the company is in accordance with customers' expectations, they will feel satisfied (Hollebeek, 2011). The previous study has shown that satisfaction, loyalty, connection, empowerment, emotional bonding, trust, and commitment would be exhibited by engaged consumers, and the engagement process included consumers' interactive experience with communities of online brands (Brodie et al., 2013). From the above description, the writer puts forward the following hypothesis:

$\boldsymbol{H}_{1}$ : There is an effect of customer engagement on customer satisfaction. 
Tuti \& Sulistia

The Customer Engagement Effect on Customer Satisfaction ...

Besides, the existence of a mutually beneficial reciprocal relationship in an engagement interaction between the customer and the company can stimulate mutual trust between the two. This interaction is outside of purchasing activities (So et al., 2016). Therefore, customers who frequently interact with the company tend to have greater trust than customers with smaller interactions or involvement. Previous research has mentioned that the engagement activities in an online-based discussion or forum with a brand (company) and other customers significantly affected the brand's trust (Mosavi \& Kenarehfard, 2013). Consumer (community) engagement is a strong predictor of brand trust and affects the brand's trust. Brand engagement could also have a stronger bond with the brand's loyalty (Dessart et al., 2016). From the above description, the writer proposes the following hypothesis:

$\boldsymbol{H}_{2}$ : There is an effect of customer engagement on brand trust.

Moreover, the brand's loyalty represents a deep commitment by customers to make certain brand repeat purchases consistently (Oliver, 1999). Meanwhile, customer engagement represents the relationship between customers and brands outside of purchasing activities (So et al., 2016). Customers who have high engagement tend to increase their liking for a product, company, or brand, indicating loyalty to them (So et al., 2014; Vivek et al., 2012). A previous study revealed that controlling product and brand level would affect brand trust and finally determine loyalty (Chaudhuri \& Holbrook, 2001). Then, satisfaction, loyalty, connection, empowerment, emotional bonding, trust, and commitment would be exhibited by engaged consumers, and the engagement process included consumers' interactive experience with communities of the online brand (Brodie et al., 2013). From the above description, the writer proposes the following hypotheses:

$\boldsymbol{H}_{3}$ : There is an effect of customer engagement on brand loyalty.

$\boldsymbol{H}_{4}$ : There is an indirect effect of customer engagement on brand trust through customer satisfaction.

$\boldsymbol{H}_{5}:$ There is an indirect effect of customer engagement on brand loyalty through customer satisfaction and brand trust.

\section{Customer Satisfaction}

Customer satisfaction is a cumulative satisfaction, also known as the final assessment of customers according to their experience with product brands (Han et al., 2018). Customer satisfaction can be formed through consumer affective responses such as enjoyment, joy, and pleasure when having the experience of using the services of a brand or company (Gummerus et al., 2012). Fornell mentioned three aspects to measure customer satisfaction: overall satisfaction, confirmation of expectation, and comparison to ideal (Fornell, 2016). Customer satisfaction also includes satisfaction, happiness, curiosity, surprise, and other forms of expression. It is suggested that customer satisfaction, as a 
Tuti \& Sulistia

The Customer Engagement Effect on Customer Satisfaction ...

psychological response, results from comparing customers' actual perceptions of the service and their expectations of the service. Thus, customers will buy a product or service because this kind of product or service can meet their needs (Lai et al., 2021)

The level of customer satisfaction obtained from using a product can be determined by two elements: product formulation and packaging (Bureau, 1981). Customers who are satisfied with a brand's performance (company) show the strength of their trust ( $\mathrm{Ha} \&$ Perks, 2005). Previous research found a significant effect of customer satisfaction on the brand's trust (Gummerus et al., 2012; Mosavi \& Kenarehfard, 2013). A previous study also found that customer trust for the brand is essential for brand satisfaction (Zehir et al., 2011). From the above explanation, the writer proposes the following hypothesis:

$\boldsymbol{H}_{6}$ : There is an effect of customer satisfaction on brand trust.

\section{Brand Trust}

Trust of the brand is the intention of the average customer relying on the ability of a brand to implement its stated functions (Chaudhuri \& Holbrook, 2001). Others stated that brand trust includes a process that is thought out well and considered carefully (Zehir et al., 2011). Three aspects are crucial to measuring the brand's trust (Ndubisi, 2007): the brand promises to prove reliable, consistent with providing quality service, and respect customers.

Trust and loyalty have a close relationship since trust has an important role in exchange relationships (interactions), and loyalty also acts as an indicator in this valuable relationship (Chaudhuri \& Holbrook, 2001). Therefore, it can be stated that brand trust contributed positively to brand loyalty (Mosavi \& Kenarehfard, 2013). Previous research stated a significant effect of brand trust on brand loyalty (Chaudhuri \& Holbrook, 2001; So et al., 2016; Zehir et al., 2011). Brand trust is also positively correlated with brand loyalty (Zehir et al., 2011). From the above description, the writer proposes the following hypothesis:

$\boldsymbol{H}_{7}$ : There is an effect of brand loyalty on brand trust.

\section{Brand Loyalty}

The brand's loyalty generally connotes a habit in purchasing behavior expressed from time to time by the determinants of purchasing decisions by comparing several brand alternatives as part of the psychological process (Han et al., 2018). Brand loyalty is also seen as a positive response after a customer makes a purchase and feels happy and satisfied with the quality of a product and the benefits provided by the brand (Shanahan et al., 2019). 
Tuti \& Sulistia

The Customer Engagement Effect on Customer Satisfaction ...

Customer loyalty is formed based on the assumption that customers initially process information to create beliefs, use that belief as a foundation for attitudes (attitudinal), and then make a behavior or behavioral decision to keep using the same brand (Oliver, 1999). Brand loyalty can be measured by three things: real customer behavior and sympathy for the brand, their individual performance rating with a product and sympathy for the brand, and the customer's satisfaction with a product and sympathy for the brand (Kotler \& Pfoertsch, 2010).

\section{Conceptual Model}

Based on the literature reviewed, the following conceptual model was developed to be tested:

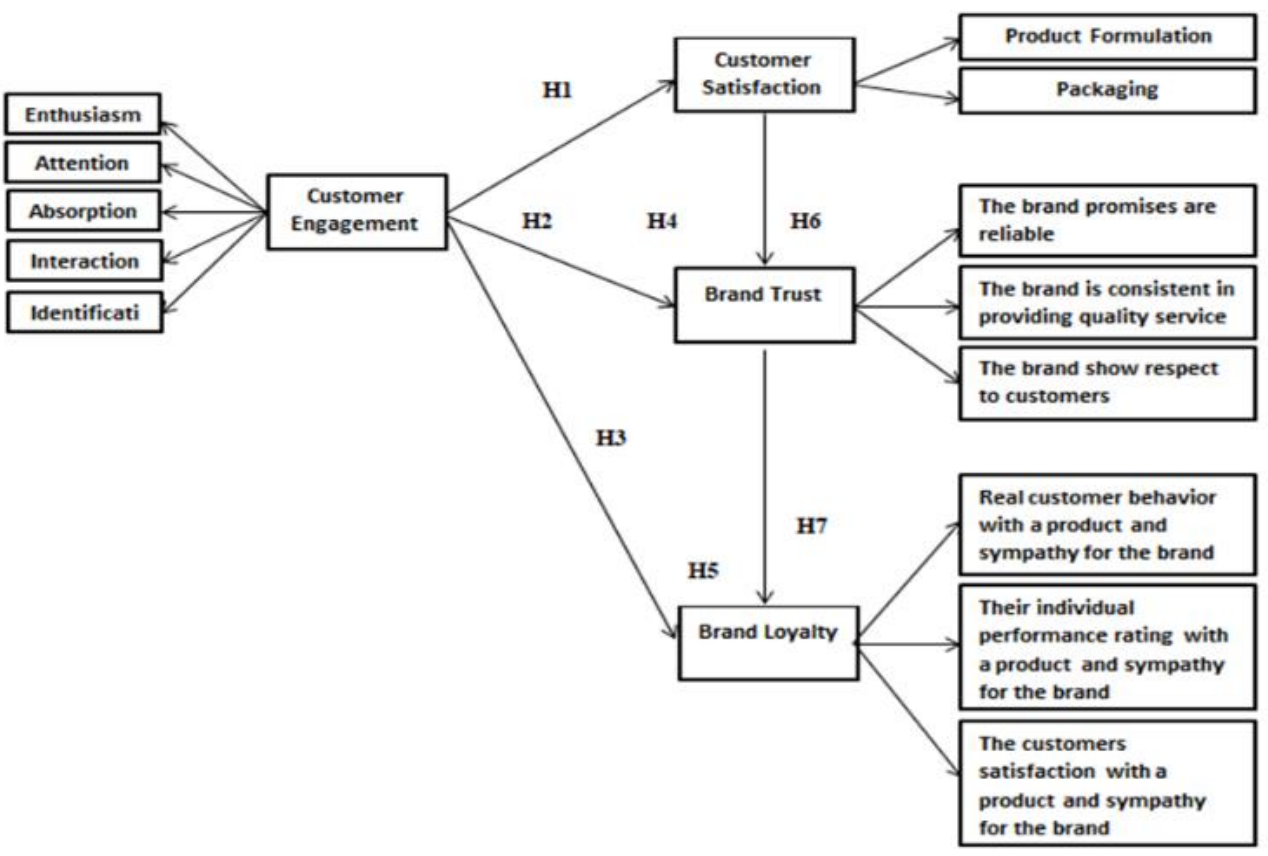

Figure 1 Conceptual Model for the Study

\section{Research Methods}

The study analyses were based on the quantitative method (Sekaran \& Bougie, 2016). The exogenous variable in this study was customer engagement, while the endogenous variables were customer satisfaction, trust of the brand, and brand loyalty. For data analysis, the study utilized LISREL 8.8. Then, the factor analysis was confirmatory and performed for all the latent constructs to access the fit model, convergent validity, and discriminant validity (Memon et al., 2017). The method used to test the reliability and validity was the Pearson product-moment correlation coefficient and the method of Cronbach's alpha. The second step included analysis of data by SEM, a second-generation multivariate analysis technique combining path analysis and factor analysis to allow 
Tuti \& Sulistia

The Customer Engagement Effect on Customer Satisfaction ...

researchers to test simultaneously and estimate the relationship between multiple latent variables, which are independent and dependent with several indicators and mediators and test models and effects of moderator, models in non-linear form, and measurement errors (Latan \& Ramli, 2013).

\section{Sample/Participants}

The target population of this study was customers who made purchases from December 2019 to February 2020. The convenience sampling method was adapted to collect data, and the online survey was distributed to respondents who had made two or more purchases. Over two months of data collection, 200 questionnaire responses were valid out of 203 questionnaires distributed. The writer used a sample size of 100 or 200 as the minimum for SEM (Boomsma \& Hoogland, 2001; Maccallum et al., 1999).

\section{Instrument}

Concerning discriminant and convergent validity, Table 1 shows the standardized factor loadings and constructs reliability from convergent validity (Hair et al., 2010). A total of 19 items were used in the measurement model. There were no validity and reliability issues in the data since all the loadings and constructs met the recommended reliability and validity criteria (Henseler et al., 2014). First, each measurement factor, significant in loading, ranged from 0.700 to 0.850 . The critical ratio ( $t$-value) was higher than the critical level of 1.96 and the p-value of 0.05 (5\%). Secondly, for construct reliability, the composite reliability and Cronbach's Alpha of the entire constructs were greater than the recommended 0.70 cut-offs (Nunnaly \& Bernstein, 1994). The values were between 0.730 and 0.830 , suggesting that each factor was measured well by all measurements significantly. Third, the average variance extracted (AVE) values ranged from 0.510 to 0.610 , higher than 0.5 , providing evidence of convergent validity (Hair et al., 2010). The discriminant validity analysis results presented in Table 1 also reveal that all constructs were distinct from each other, and all other correlations had fewer values than the square root of the AVE for each individual construct (Henseler et al., 2014; Steenkamp \& van Trijp, 1991).

\section{Results and Discussion}

\section{Descriptive Analysis}

The analysis of respondents' profiles indicates that the majority, $62 \%$ of them, were $21-$ 30 years old, and $49 \%$ were college students. $72 \%$ of respondents had the sources of information through social media, and most of the respondents, $82 \%$, purchased between 3-5 times. 
Tuti \& Sulistia

The Customer Engagement Effect on Customer Satisfaction ...

Table 1 Demographic Profile of the Respondents

\begin{tabular}{|c|c|c|}
\hline Demographic Variable & Frequency & Percent \\
\hline \multicolumn{3}{|l|}{ Age } \\
\hline Below 20 & 26 & 16 \\
\hline $21-50$ & 131 & 62 \\
\hline $31-40$ & 41 & 21 \\
\hline Above 40 & 2 & 1 \\
\hline \multicolumn{3}{|l|}{ Profession } \\
\hline Private Job & 46 & 23 \\
\hline Student & 100 & 54 \\
\hline Government Job & 23 & 5 \\
\hline Entrepreneur & 20 & 8 \\
\hline \multicolumn{3}{|l|}{ Information Source } \\
\hline Family & 38 & 16 \\
\hline Social Media & 133 & 72 \\
\hline Friend & 29 & 12 \\
\hline \multicolumn{3}{|l|}{ Buying Frequency } \\
\hline Twice & 3 & 5 \\
\hline 2 - 5 times & 159 & 82 \\
\hline More than 5 & 38 & 14 \\
\hline Total & 200 & 100 \\
\hline
\end{tabular}

\section{Reliability and Validity Analysis}

CFA was done to test the measurement model, data appropriateness, discriminant validity, and convergent. Table 2 displays the standardized factor loadings and constructs reliability from convergent validity (Hair et al., 2010). A total of 19 items were in use in the measurement model. Then, there were no validity and reliability issues in the data because all the loadings and constructs met the recommended reliability and validity criteria (Henseler et al., 2014). First, each measurement had a significant factor loading ranging from 0.700 to 0.850 . The critical ratio ( $t$-value) was higher than the critical level of 1.96 and the p-value of 0.05 (5\%). Secondly, for construct reliability, the composite reliability and Cronbach's Alpha of all the constructs were greater than the one recommended 0.70 cut-offs (Nunnaly \& Bernstein, 1994). The values ranged between 0.730 and 0.830 , suggesting that each factor was measured in a good way by all measurements significantly. Third, the average variance extracted (AVE) values ranged from 0.510 to 0.610 , higher than 0.5 , proving convergent validity (Hair et al., 2010). The discriminant analysis of validity results presented in Table 2 reveals that all constructs were distinct from each other. In addition, all the other correlations had fewer values than the square root of the AVE for every individual construct (Henseler et al., 2014). 
Tuti \& Sulistia

The Customer Engagement Effect on Customer Satisfaction ...

Table 2 Construct Reliability, Average Variance Extracted, and Discriminant Validity

\begin{tabular}{|c|c|c|c|c|c|c|}
\hline Indicator & $\begin{array}{l}\text { Standardized } \\
\text { Loading }\end{array}$ & $\begin{array}{l}\text { Error } \\
\text { Variance }\end{array}$ & $\begin{array}{c}\text { t- } \\
\text { statistic }\end{array}$ & $\begin{array}{l}\text { Construct } \\
\text { Reliability }\end{array}$ & $\begin{array}{l}\text { Average } \\
\text { Variance } \\
\text { Extracted }\end{array}$ & $\begin{array}{c}\text { Discriminant } \\
\text { validity }\end{array}$ \\
\hline $\mathrm{X} 1$ & 0.71 & 0.49 & 10.36 & \multirow[t]{5}{*}{0.73} & \multirow[t]{5}{*}{0.52} & \multirow[t]{5}{*}{0.72} \\
\hline$x 2$ & 0.72 & 0.48 & 16.28 & & & \\
\hline X3 & 0.71 & 0.49 & 7.71 & & & \\
\hline $\mathrm{X} 4$ & 0.85 & 0.27 & 10.01 & & & \\
\hline$\times 5$ & 0.7 & 0.51 & 8.99 & & & \\
\hline $\mathrm{Y} 1,1$ & 0.78 & 0.39 & 9.23 & \multirow[t]{4}{*}{0.74} & \multirow[t]{4}{*}{0.51} & \multirow[t]{4}{*}{0.71} \\
\hline $\mathrm{Y} 1,2$ & 0.77 & 0.41 & 29.37 & & & \\
\hline$Y 1,3$ & 0.79 & 0.38 & 18.03 & & & \\
\hline $\mathrm{Y} 1,4$ & 0.85 & 0.27 & 5.94 & & & \\
\hline$Y 2,1$ & 0.8 & 0.36 & 9.06 & \multirow[t]{5}{*}{0.83} & \multirow[t]{5}{*}{0.61} & \multirow[t]{5}{*}{0.78} \\
\hline$Y 2,2$ & 0.78 & 0.39 & 9.79 & & & \\
\hline$Y 2,3$ & 0.84 & 0.29 & 7.02 & & & \\
\hline$Y 2,4$ & 0.7 & 0.51 & 13.4 & & & \\
\hline$Y 2,5$ & 0.79 & 0.37 & 8.06 & & & \\
\hline$Y 3,1$ & 0.79 & 0.38 & 16.16 & \multirow[t]{5}{*}{0.78} & \multirow[t]{5}{*}{0.58} & \multirow[t]{5}{*}{0.76} \\
\hline$Y 3,2$ & 0.77 & 0.4 & 26.65 & & & \\
\hline$Y 3,3$ & 0.85 & 0.28 & 9.76 & & & \\
\hline$Y 3,4$ & 0.7 & 0.52 & 10.79 & & & \\
\hline$Y 3,5$ & 0.83 & 0.32 & 10.46 & & & \\
\hline
\end{tabular}

\section{Confirmatory Factor Analysis}

This study carried out a confirmatory factor analysis to evaluate the measurement model's overall validity and fit of the constructs. The key goodness-of-fit indices for the measurement model were tested (Hu \& Bentler, 1999).

Table 3 Model Fit Indices for the Measurement Model

\begin{tabular}{lc}
\hline Model ECVI & 1.91 \\
Independence ECVI & 26.35 \\
Saturated ECVI & 1.91 \\
(RMSEA) & 0.071 \\
Model CAIC (Consistent Akaike Information Criterion) & 551.84 \\
Independence CAIC & 5325.73 \\
Saturated CAIC & 1196.68 \\
Model AIC & 379.9 \\
Independence AIC & 5244.07 \\
Saturated AIC & 380 \\
NFI & 0.94 \\
NNFI & 0.97 \\
CFI & 0.97 \\
IFI & 0.97 \\
RF & 0.93 \\
GFI & 0.70 \\
AGFI & 0.62 \\
\hline
\end{tabular}


Tuti \& Sulistia

The Customer Engagement Effect on Customer Satisfaction ...

Based on the model fit of measurement, the overall chi-square for the model of measurement was the Chi-square, and Chi-square to degrees of freedom were $\times 2=$ 451,609 , Normed Fit Index (NFI) $=0.94$, Independence ECVI $=26,35$, Independence CAIC $=5325,73$, Independence AIC $=5244,07$, Non-Normed fix index $(\mathrm{NNFI})=0,97$, and Root Mean Square Error of Approximation (RMSEA) $=0.074$, indicating adequate fit (Hair et al., 2010; Hu \& Bentler, 1999). Though the GFI did not fulfill their suggested cut-off value of 0.90, respectively, all other fit indices met the recommended value. Thus, the model provided strong proof of the model's good fit (Steiger, 1980), as shown in the result that can be checked in Table 3.

\section{Structural Model and Hypothesis Tests}

There exist two exogenous (independent) factors and two endogenous (dependent) factors. For the structural model, the results showed that the proposed model obtained overall reasonably acceptable fit to the data, with $\mathrm{GFI}=0.69, \mathrm{NFI}=0.94, \mathrm{IFI}=0.97, \mathrm{RFI}=$ $0.93, \mathrm{CFI}=0.97$, and RMSEA $=0.075$.

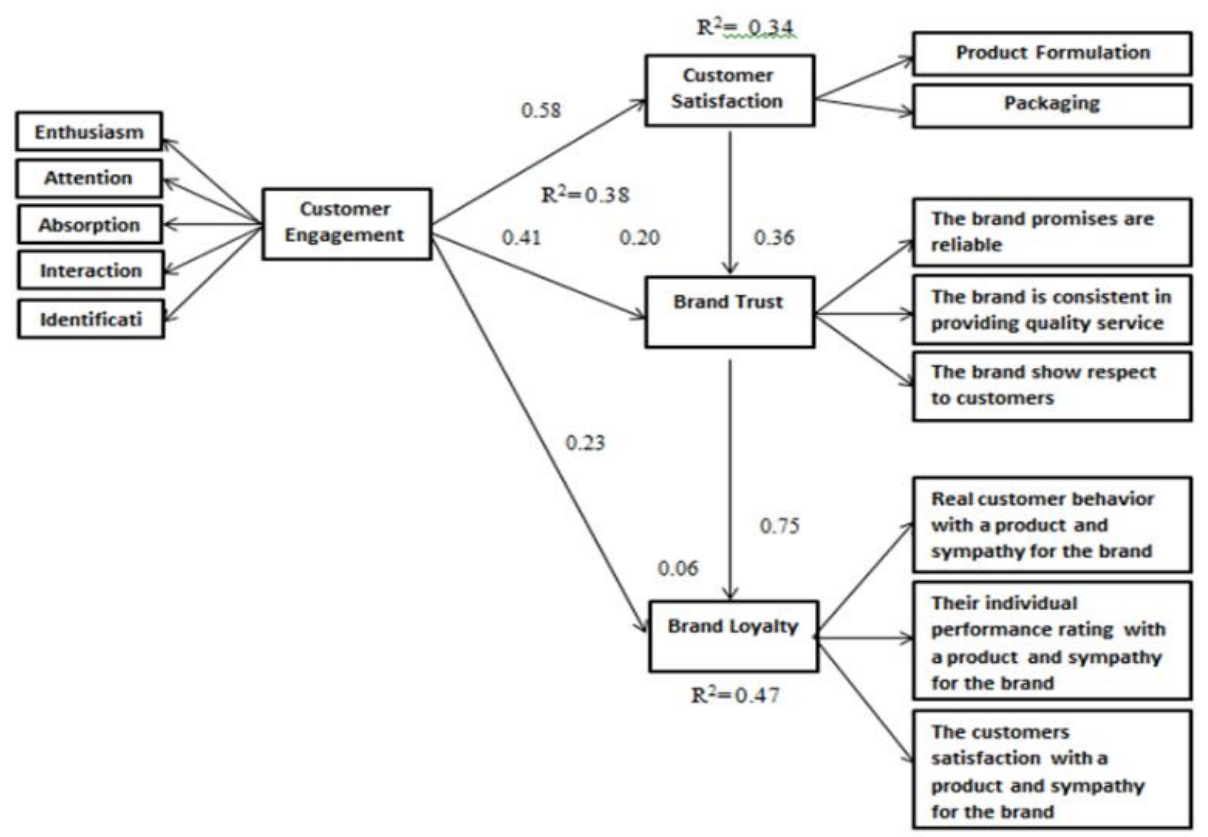

Figure 2 Model of Research with Standardized Path Coefficients $(p<0.05)$

\section{Hypotheses Testing}

The summary of the hypothesis testing results with structural path estimates is displayed in Table 3. Then, Figure 2 displays the path coefficients for testing the hypothesis. 
Tuti \& Sulistia

The Customer Engagement Effect on Customer Satisfaction ...

Table 4 Summary of Hypothesis Tests

\begin{tabular}{lccc}
\multicolumn{1}{c}{ Path } & Estimation & Nilai-t & Supported/Not Supported \\
\hline $\begin{array}{l}\text { Customer Engagement }(\mathrm{X}) \rightarrow \\
\text { Customer Satisfaction (Y1) }\end{array}$ & 0.58 & 5.31 & Supported \\
$\begin{array}{l}\text { Customer Engagement }(\mathrm{X}) \rightarrow \\
\text { Brand Trust (Y2) }\end{array}$ & 0.41 & 3.05 & Supported \\
$\begin{array}{l}\text { Customer Engagement (X) } \\
\rightarrow \text { Brand Loyalty (Y3) }\end{array}$ & 0.23 & 2.01 & Supported \\
$\begin{array}{l}\text { Customer Satisfaction (Y1) } \rightarrow \\
\text { Brand Trust (Y2) }\end{array}$ & 0.36 & 2.69 & Supported \\
$\begin{array}{l}\text { Brand Trust (Y2) } \rightarrow \text { Brand } \\
\text { Loyalty (Y3) }\end{array}$ & 0.75 & 5.27 & Supported \\
$\begin{array}{l}\text { Customer Engagement }(\mathrm{X}) \rightarrow \\
\text { Customer Satisfaction (Y1) } \rightarrow\end{array}$ & 0.20 & 2.69 & Supported \\
Brand Trust (Y2) \\
$\begin{array}{l}\text { Customer Engagement (X) } \rightarrow \\
\text { Brand Loyalty (Y3) } \rightarrow \\
\text { Customer Satisfaction (Y1) } \rightarrow\end{array}$
\end{tabular}

Figure 2 and Table 3 display path analysis results based on the determination of multiple coefficients of (R2), path coefficients ( $\beta$ ), and t-values. The results portrayed that all hypotheses were supported except for $\mathrm{H} 5$ (customer engagement to brand loyalty, with t-value $=0.47$ ). As predicted, coefficients of the positive path were significant between two exogenous variables (customer engagement) and three variables endogenous (customer satisfaction, brand trust, and brand loyalty), including $\mathrm{H} 1$ : customer engagement $\rightarrow$ satisfaction of customer $(\beta=0.58, t=5.31), H 2$ : customer engagement $\rightarrow$ brand trust $(\beta=0.41, t=3.05), H 3$ : customer engagement $\rightarrow$ brand loyalty $(\beta=0.23$, $t=2.01), H 4$ : customer engagement $\rightarrow$ customer satisfaction $\rightarrow$ brand trust $(\beta=0.20$, $t=2.69$ ), H5: customer engagement $\rightarrow$ brand loyalty $\rightarrow$ customer satisfaction $\rightarrow$ brand trust $(\beta=0.06, t=5.27), H 6:$ customer satisfaction $\rightarrow$ brand trust $(\beta=0.36, t=2.69)$, and $\mathrm{H7}$ : brand trust $\rightarrow$ brand loyalty $(\beta=0.75, t=5.27)$. Thus, the results revealed that the entire variables had a significant effect. The customer explained $34 \%$ of the variance of customer satisfaction. Furthermore, customer engagement and customer satisfaction explained $38 \%$ of the variance of brand trust, and brand trust and customer engagement explained $47 \%$ of the brand loyalty variance.

In addition, this study explores how customer engagement influenced customer satisfaction, brand trust, and brand loyalty, either directly or indirectly. Customer engagement was discovered to have a positive and significant relationship with customer satisfaction, brand loyalty, and brand trust. Through customer satisfaction, customer engagement had an indirect positive and significant relationship with brand trust. Through customer satisfaction and brand trust, customer engagement had an indirect significant and positive relationship with brand loyalty. In addition, customer satisfaction had a significant positive relationship with brand trust, and brand trust had a significant positive relationship with brand loyalty. 
Tuti \& Sulistia

The Customer Engagement Effect on Customer Satisfaction ...

These findings demonstrate that customer engagement has an important role in causing customer satisfaction, and it will lead to brand trust and ultimately increase brand loyalty. These findings also prove to be consistent with previous literature. In his research, Hollebeek concluded that if service or company response is in accordance with customer expectations in customer interaction with the company, the customer will feel satisfied, and vice versa (Hollebeek, 2011). The existence of mutually beneficial relationships in an engagement interaction between customers and companies can stimulate mutual trust between the two, and such interactions are outside the purchasing activities. Customers feel trust since they believe in the reliability or ability and integrity that the company has in providing good responses when interacting. It means that high engagement indicates higher customer confidence in the company in an interaction relationship (So et al., 2014). Highly engaged customers also tend to increase their likeness towards a product, company, or brand, indicating loyalty (So et al., 2014; Vivek et al., 2012). The tactics classified as customer engagement content developed include enthusiasm, absorption, attention, interaction, and identification.

Then, Ha with Perks, in their research, concluded the fact that customers who are satisfied with the performance of a brand (company) show their strong trust so that customer satisfaction can be understood as an association of the spread of positive information by customers on previous interaction experiences with the company, which impacts their trust in the company. Because satisfied customers will continue to use the services of the same brand (company) continuously and make repurchases, the more satisfied the customers, the more loyal they are to a particular brand (Ha \& Perks, 2005).

Moreover, brand trust is defined as the ability of the brand to be relied upon based on the belief of the customer that the product is capable of meeting the promised value. It is also brand intentions based on the customer's belief that the brand can put the interests of customers first. These customer beliefs arise from repeated perceptions and the existence of positive customer experience and learning. Thus, customers will feel that the brand cares about their needs and is interested in the customer's heart. According to Chauduri and Holbrook, brand trust is the atheism of brand loyalty, improved customer positive brand evaluation, and then brand trust can build brand loyalty as a result of the creation of high value on the exchange relationship between customer and brand or company; because through such positive evaluation, customer can find out how much the level of risk acceptance if they utilize the company services (Chaudhuri \& Holbrook, 2001). If the risk acceptance opportunity is tiny, the customer does not hesitate to add his commitment to the company (So et al., 2014). In this regard, trust and loyalty have a close relationship because trust has an important role in relationship exchanges (interactions), and loyalty also serves as an indicator in such valuable relationships (Chaudhuri \& Holbrook, 2001). It can therefore be said that brand trust positively affects brand loyalty.

Brand loyalty reflects behavioral aspects that indicate consistent repurchases of a brand by customers and aspects of attitude that indicate the customer's preferred aspect of a brand. Customer loyalty is formed based on the assumption that customers initially process information to create beliefs, then they use those beliefs as an attitudinal basis, and then make behavioral decisions to stick with the same brand (Oliver, 1999). 
Tuti \& Sulistia

The Customer Engagement Effect on Customer Satisfaction ...

\section{Conclusion}

Like all studies, this study has limitations that should be written down. First, the generalization of study results may be limited due to sampling design. The study used convenience sampling from 203 respondents who had made more than twice purchases and had been repeater shoppers at an online shop. Hence, it is suggested that studies in the future should be expanded to include large populations and all types of online shops. Moreover, this study's data was taken by women, which may lead to bias concerns. Gender-balanced data is better for checking buyers' perceptions of customer engagement variations. In addition, future studies can also test other variables.

The study results provide some important theoretical and managerial implications. This model shows that a well-engaged customer will increase purchases and create repeater buyers. It is one study that examines how customer engagement directly affects customer satisfaction, brand loyalty, and brand trust.

In managerial terms, this research also suggests important managerial implications for practitioners. Customer engagement affects satisfaction, trust, and loyalty. The results imply that comprehending consumer preferences is important for businesses. To cut down consumers' lack of interest in product purchases, businesses should focus on customer engagement to make them enjoy and grow their trust to order and give their loyalty to brands. In other words, the company must provide good engagement to generate trust and increase buyer loyalty to the brand.

\section{References}

Anderson, E. W., \& Mittal, V. (2000). Strengthening the Satisfaction-Profit Chain. Journal of Service Research, 3(2), 107-120. https://doi.org/10.1177/109467050032001

Boomsma, A., \& Hoogland, J. J. (2001). The Robustness of LISREL Modeling Revisited. In R. Cudeck, S. du Toit, \& D. Sörbom (Eds.). Structural Equation Models: Present and Future. A Festscbrift in Honor of Karl Jöreskog (139-168). Lincolnwood, IL: Scientific Software International.

Brodie, R. J., Ilic, A., Juric, B., \& Hollebeek, L. (2013). Consumer engagement in a virtual brand community: An exploratory analysis. Journal of Business Research, 66(1), 105-114. https://doi.org/10.1016/i.jbusres.2011.07.029

Bureau, J. R. (1981). Brand Management Planning and Control (1st Ed.). Palgrave MacMillan.

Chaudhuri, A., \& Holbrook, M. B. (2001). The Chain of Effects from Brand Trust and Brand Affect to Brand Performance: The Role of Brand Loyalty. Journal of Marketing, 65(2), 81-93. https://doi.org/10.1509/jmkg.65.2.81.18255

Cho, Y. S., Rha, H. S., \& Burt, S. (2015). The impact of customer awareness of manufacturer name disclosure on retail brand attitudes and loyalty in Korea. Journal of Retailing and Consumer Services, 22, 128-137. https://doi.org/10.1016/i.jretconser.2014.10.008

Dessart, L., Veloutsou, C., \& Morgan-Thomas, A. (2016). Capturing consumer engagement: duality, dimensionality and measurement. Journal of Marketing Management, 32(5-6), 399426. https://doi.org/10.1080/0267257X.2015.1130738

Fornell, C. (1992). A National Customer Satisfaction Barometer: The Swedish Experience. Journal of Marketing, 56(1), 6-21. https://doi.org/10.1177/002224299205600103 
Tuti \& Sulistia

The Customer Engagement Effect on Customer Satisfaction ...

Gummerus, J., Liljander, V., Weman, E., \& Pihlström, M. (2012). Customer engagement in a Facebook brand community. Management Research Review, 35(9), 857-877. https://doi.org/10.1108/01409171211256578

Ha, H.-Y., \& Perks, H. (2005). Effects of consumer perceptions of brand experience on the web: brand familiarity, satisfaction and brand trust. Journal of Consumer Behaviour, 4(6), 438-452. https://doi.org/10.1002/cb.29

Hair, J., Black, W., Babin, B., Anderson, RE., T., \& Atham, R. (2010). Multivariate Data Analysis (5th Ed). Prentice Hall.

Han, H., Nguyen, H. N., Song, H., Chua, B.-L., Lee, S., \& Kim, W. (2018). Drivers of brand loyalty in the chain coffee shop industry. International Journal of Hospitality Management, 72, 86-97. https://doi.org/10.1016/i.ijhm.2017.12.011

Henseler, J., Ringle, C. M., \& Sarstedt, M. (2014). A new criterion for assessing discriminant validity in variance-based structural equation modeling. Journal of the Academy of Marketing Science, 43(1), 115-135. https://doi.org/10.1007/s11747-014-0403-8

Hollebeek, L. D. (2011). Demystifying customer brand engagement: Exploring the loyalty nexus. Journal of Marketing Management, 27(7-8), 785-807. https://doi.org/10.1080/0267257x.2010.500132

Hu, L., \& Bentler, P. M. (1999). Cutoff criteria for fit indexes in covariance structure analysis: Conventional criteria versus new alternatives. Structural Equation Modeling: $A$ Multidisciplinary Journal, 6(1), 1-55. https:// doi.org/10.1080/10705519909540118

Hwang, S., Lee, M., Park, E., \& del Pobil, A. P. (2021). Determinants of customer brand loyalty in the retail industry: A comparison between national and private brands in South Korea. Journal of Retailing and Consumer Services, 63, 102684. https://doi.org/10.1016/j.jretconser.2021.102684

Kaplan, A. M., \& Haenlein, M. (2010). Users of the world, unite! The challenges and opportunities of Social Media. Business Horizons, 53(1), 59-68. https://doi.org/10.1016/j.bushor.2009.09.003

Kosiba, J. P. B., Boateng, H., Okoe Amartey, A. F., Boakye, R. O., \& Hinson, R. (2018). Examining customer engagement and brand loyalty in retail banking. International Journal of Retail \& Distribution Management, 46(8), 764-779. https://doi.org/10.1108/IJRDM$\underline{08-2017-0163}$

Kotler, P., \& Pfoertsch, W. (2010). Ingredient branding: Making the invisible visible. Springer Berlin Heidelberg.

Lai, P.-L., Jang, H., Fang, M., \& Peng, K. (2022). Determinants of customer satisfaction with parcel locker services in last-mile logistics. The Asian Journal of Shipping and Logistics, 38(1), 25-30. https://doi.org/10.1016/j.ajsl.2021.11.002

Latan, H., \& Ramli, N. A. (2013). The Results of Partial Least Squares-Structural Equation Modelling Analyses (PLS-SEM). SSRN Electronic Journal. https://doi.org/10.2139/ssrn.2364191

MacCallum, R. C., Widaman, K. F., Zhang, S., \& Hong, S. (1999). Sample size in factor analysis. Psychological Methods, 4(1), 84-99. https://doi.org/10.1037/1082-989X.4.1.84

Memon, M. A., Ting, H., Ramayah, T., Chuah, F., \& Cheah, J. (2017). A Review of the Methodological Misconceptions and Guidelines Related to the Application of Structural Equation Modeling: A Malaysian Scenario. Journal of Applied Structural Equation Modeling, 1(1), 1-13. https://doi.org/10.47263/jasem.1(1)01

Mosavi, S.A., \& Kenarehfard, M. (2013). The Impact of Value Creation Practices on Brand Trust and Loyalty in a Samsung Galaxy Online Brand Community in Iran. Mobile Marketing Association, IJMM Winter, 8(2), 75-84.

Ndubisi, N. O. (2007). Relationship marketing and customer loyalty. Marketing Intelligence and Planning, 25(1), 98-106. https://doi.org/10.1108/02634500710722425 
Nunnaly, Ju. C., \& Bernstein, I. H. (1994). Psychometric Theory (3rd Ed.). McGraw-Hill.

Oliver, R. L. (1999). Whence Consumer Loyalty? Journal of Marketing, 63(4_suppl1), 33-44. https://doi.org/10.1177/00222429990634s105

Rahmawati, E., \& Aji, S. (2015). Pengaruh customer engagement terhadap kepuasan pelanggan dan kepercayaan merek serta dampaknya pada loyalitas merek. Jurnal Riset Ekonomi dan Manajemen, 15(2), 246-261. http://dx.doi.org/10.17970/jrem.15.150204.ID

Sashi, C. M. (2012). Customer engagement, buyer - seller relationships, and social media. Management Decision, 50(2), 253-272. https://doi.org/10.1108/00251741211203551

Sekaran, U., \& Bougie, R. (2016). Research Methods for Business: A Skill-Building Approach (7th Ed). West Sussex: Wiley \& Sons.

Shanahan, T., Tran, T. P., \& Taylor, E. C. (2019). Getting to know you: Social media personalization as a means of enhancing brand loyalty and perceived quality. Journal of Retailing and Consumer Services, 47, 57-65. https://doi.org/10.1016/i.jretconser.2018.10.007

So, K. K. F., King, C., \& Sparks, B. (2014). Customer Engagement With Tourism Brands. Journal of Hospitality \& Tourism Research, 38(3), 304-329. https://doi.org/10.1177/1096348012451456

So, K. K. F., King, C., Sparks, B. A., \& Wang, Y. (2014). The Role of Customer Engagement in Building Consumer Loyalty to Tourism Brands. Journal of Travel Research, $55(1), 64$ 78. https://doi.org/10.1177/0047287514541008

Steenkamp, J.-B. E. M., \& van Trijp, H. C. M. (1991). The use of lisrel in validating marketing constructs. International Journal of Research in Marketing, 8(4), 283-299. https://doi.org/10.1016/0167-8116(91)90027-5

Steiger, J. H. (1980). Tests for comparing elements of a correlation matrix. Psychological Bulletin, 87(2), 245-251. https://doi.org/10.1037/0033-2909.87.2.245

Strauss, J., \& Frost, R. (2014). E-marketing, International Edition, (7th Ed). Pearson.

Vivek, S. D. (2009). A scale of consumer engagement. Dissertation. University of Alabama.

Vivek, S. D., Beatty, S. E., \& Morgan, R. M. (2012). Customer Engagement: Exploring Customer Relationships Beyond Purchase. Journal of Marketing Theory and Practice, 20(2), 122-146. https://doi.org/10.2753/mtp1069-6679200201

Zehir, C., Şahin, A., Kitapç1, H., \& Özşahin, M. (2011). The Effects of Brand Communication and Service Quality In Building Brand Loyalty Through Brand Trust; The Empirical Research On Global Brands. Procedia - Social and Behavioral Sciences, 24, 1218-1231. https://doi.org/10.1016/j.sbspro.2011.09.142 